Nig. J. Pure \& Appl. Sci. Vol. 34 (Issue 2, 2021)
e-ISSN 2756-4045
Life Sciences, Univ. of Ilorin, Nigeria
www.njpas.com.ng

\title{
Crude Ethanolic Stem Bark Extract of Zanthoxylum zanthoxyloides and Its Fractions: In- Vitro and In-Vivo Antiplasmodial Activity
}

\author{
Sulaiman S. Rukayyah"1, Jigam, Audu Ali², Abubakar, Abdulkadir ${ }^{2}$ and Salau, Rasaq Bolakale ${ }^{3}$
}

Page | 4153

\author{
${ }^{1}$ Department of Biochemistry, Ibrahim Badamasi Babangida University, Lapai, Nigeria \\ ${ }^{2}$ Department of Biochemistry, Federal University of Technology, Minna, Nigeria \\ ${ }^{3}$ Department of Chemistry, Federal University of Technology, Minna, Nigeria
}

Date Received: 11-06-2021

Date Accepted: 04-09-2021

DOI: https://doi.org/10.48198/NJPAS/21.B03

\section{ABSTRACT}

Malaria is a global problem, as treatment failure has hampered the efficacy of most anti-malarial medications. The goal of this study was to see if stem bark extract from Zanthoxylum zanthoxyloides had antiplasmodial properties that could be used to treat both susceptible and resistant parasites. The stem bark of Z. zanthoxyloides (500g) was crushed and extracted with ethanol. The extract was tested for antiplasmodial activity in vitro against the chloroquine-sensitive (CQS) strain NF54 and chloroquineresistant strains (CQR) K1 of P. falciparum, as well as in vivo against the CQS(NK65) strain of P. berghei at 100,200 , and $400 \mathrm{mg} / \mathrm{kg}$ bw. Bioassay-guided fractionation of the extract was performed. The crude extract had an in vitro activity of 1076.456 .4 and $1315.1121 .6 \mathrm{ng} / \mathrm{ml}$ against chloroquine sensitive and resistant parasites, respectively while standard drugs (chloroquine and artesunate) were $10.94 \mathrm{nM}$ (3478.92 $\mathrm{ng} / \mathrm{ml})$ and $9.24 \mathrm{nM}(3215.52 \mathrm{ng} / \mathrm{ml})$ for CQS and $310.68 \mathrm{nM}(98796 \mathrm{ng} / \mathrm{ml})$ and $10.94 \mathrm{nM}(3650.52$ $\mathrm{ng} / \mathrm{ml}$ ) for CQR respectively. At Day 7, mice treated with 100, 200, and $400 \mathrm{mg} / \mathrm{kg}$ bw crude extract had parasite densities of 1159, 928, and 869 parasites/ $\mu 1$, respectively (compared to positive control that had 123 parasites $/ \mu 1)$. In vitro antiplasmodial activity was best in the $\mathrm{K} 2, \mathrm{~K} 4$, and $\mathrm{K} 6$ fractions $\left(\mathrm{IC}_{50}\right.$ were 6670 , 6890, and $6480 \mathrm{ng} / \mathrm{ml}$ ), but in vivo antiplasmodial activity was best in the K4 fraction (1183 parasites/ $\mu 1)$.The stem bark extract of $Z$. zanthoxyloides have remarkable antiplasmodial activity against both chloroquine sensitive and drug resistant $P$. falciparum supporting it ethnomedicinal use in malaria treatment. The extract of $Z$. zanthoxyloides has promising antiplasmodial activity and could be used to generate therapeutic leads against the multidrug-resistant $\mathrm{K} 1$ strain of $P$. falciparum, in addition to providing an alternative allopathic antiplasmodial medication.

Keywords: Malaria, drug-resistant parasite, treatment, zanthoxyloides

Corresponding Author: Sulaiman S. Rukayyah

Department of Biochemistry, Ibrahim Badamasi Babangida University, Lapai, Nigeria Phone: +2348065863683; Email: rukkysule82@gmail.com 


\section{Introduction}

Malaria is a global problem, as treatment failure has harmed the efficacy of most anti-malarial medications. Malaria is a deadly protozoan disease Page | 4154 caused by plasmodium parasites that spread through the bites of infected female Anopheles mosquitos. (Addisu et al., 2020) Of the 172 of Plasmodium species, six species can infect humans, $P$. malariae, P. falciparum, $P$. vivax, $P$. ovale, P. knowlesi and P. simium. (Grigg and Snounou, 2017). Malaria infection is particularly dangerous for pregnant women, children, splenectomized and immunocompromised patients, as well as healthy persons who have never been exposed to Plasmodium (Talapko et al., 2019). If left untreated, severe malaria complications can result in death. Africa have the highest incidence of malaria (94\%, i.e. 213 million) and higher death cases (93\% i.e. 380000 out of 405 000 worldwide) as a result of the disease (Forkuo et al., 2020, WHO, 2021). The disease burden is increasing rapidly, not just as a result of vector resistance to existing pesticides, but also as a result of parasite resistance to conventional medications and their negative effects (Adesina et al., 2020). Thus there is a need for new antiplasmodial drug from natural source that will be safe and also cost effective. Thus, a new antiplasmodial medication derived from natural sources that is both safe and cost effective is required.

Zanthoxylum zanthoxyloides is one of several plant extracts from the Rutaceae family that are currently utilized in the management and treatment of illnesses. Z. zanthoxyloides is a shrub of $6-12 \mathrm{~m}$ in height. It leaves are globrous and alternate. It smells like pepper when crushed. Zanthoxylum zanthoxyloides Lam also known as Fagara, orinata, is a West Africa native plant that is widely used (Image et al., 2011 and Ynalvez et al., 2012). Malaria, toothache, sickle cell anemia, elephantiasis, sexual dysfunction, paralysis, oedema, veneral illnesses, and overall bodily weakness are all treated using root or stem bark, decoctions, infusions or macerations (Guendehou et al., 2018). Because of its pungent and numbing impact on the palate when chewed, it is commonly employed in the treatment of dental caries, sore gums, and toothache.

Furthermore, some of these assertions have been pharmacologically validated. The leaves extract exhibited antidiabetic and hypolipidaemic effects (Aloke et al., 2012). Free radical scavenging and metal ion chelating properties have been observed/discovered in $Z$. zanthoxyloides stem extract (Adekunle et al., 2012). A broad-spectrum antimicrobial activity has been demonstrated for $Z$. zanthoxyloides extract (Ynalvez et al., 2012). The ethanolic extract of Z. zanthoxyloides has been found to have antibacterial action. (Orafidiya et al., 2010). Its antiparasitic activity has been found against Ascaris lumbricoides and Leishmania majo (Maximin et al., 2007 and Barnabas et al., 2011). The antiprotease and membrane stabilizing properties of Zanthoxylum zanthoxyloides extract have been proven (Image et al., 2011). Z. zanthoxyloides has also been reported to exhibit antisickling, free radical quenching and antifungal potentials (Nurain et al., 2017, Pauline et al., 2013 and Chaaiba et al., 2003). Recent investigations have also confirmed its anticancer and antiinflammatory properties (Kassim et al., 2015, Diatta et al., 2014 and Larsen et al., 2015). It has been suggested that all part of $Z$. zanthoxyloides extracts could be used as a bio-pesticide for food storage (Udo, 2011). Denloye et al. (2010) also shown $Z$. zanthoxyloides' ability to protect grains from insect infestation. Some of the bioactive compounds isolated from Zanthoxylum zanthoxyloides include burkinabins (Queiroz et al., 2006), geraniol, citronellol, limonene, $\alpha$-pinene, myrcene (Fogang et al., 2012), and alkaloids belonging to the class of acridone (Wouatsa et al., 2013). This work was designed to obtain bioactive compounds/fraction with antiplasmodial potential from $Z$. zanthoxyloides that could be used to cure both sensitive and resistant parasite infections. 


\section{Materials and Methods}

\section{Crude extract preparation}

Fresh Z. zanthoxyloides stem bark was collected and air dried at a temperature of $35-38{ }^{\circ} \mathrm{C}$. It was Page | 4155 pulverized and $0.5 \mathrm{~kg}$ of pulverised plant sample was exhaustively extracted by using ethyl alcohol under reflux at $60^{\circ} \mathrm{C}$. Rotary evaporator was used to concentrate the filterate and the concentrate was placed in a fume cupboard for complete evaporation of solvent. The extract was kept refrigerated at $-8{ }^{\circ} \mathrm{C}$ in an in air tight container.

\section{Antiplasmodial activities}

\section{In vitro antiplasmodial assay}

The antiplasmodial potential of the extract was tested against NF54 (Chloroquine sensitive) and K1 (Chloroquine resistant) strains of Plasmodium falciparum and was cultured in sealed flasks at 37 ${ }^{0} \mathrm{C}$, in a 91, 5 and 3 percent atmospheric $\mathrm{N}_{2} \mathrm{CO}_{2}$ and $\mathrm{O}_{2}$, in RPMI 1640, 25mM HEPES, $\mathrm{pH}$ 7.4, augmented with heat inactivated $10 \%$ human serum and red blood cells to attain a packed cell volume of 2 percent. Parasites at their ring stage were synchronized with $5 \%$ sorbitol by serial dilution and $1 \%$ parasitemia was used for the research work. $1 \mathrm{mg} / \mathrm{ml}$ stock solution of plant extract in dimethyl sulphoxide (DMSO) was prepared and diluted as required for each experiments, in triplicate. The stock solutions were diluted in augmented RPMI 1640 medium to yield final reaction medium containing $0.2 \%$ DMSO. An equal volume of $1 \%$ parasitemia, $4 \%$ hematocrit culture were added and gently mixed thoroughly. Equal amount of DMSO were used in the negative controls. $1 \mu \mathrm{M}$ Artesunate and $1 \mu \mathrm{M}$ Chloroquine were used as positive controls. Cultures were incubation of culture was at $37{ }^{\circ} \mathrm{C}$ for 2 days (one parasite erythrocytic life cycle). The ring stage parasites were fixed by substituting 1 percent formaldehyde in phosphate buffer solution for the serum medium. The parasitemia of treated and control cultures were compared using aliquots (50 1) of each culture added to $5 \mathrm{ml}$ round-bottom polystyrene tubes containing $0.5 \mathrm{ml} 0.1$ percent Triton X- 100 and $1 \mathrm{nM}$ YOYO nuclear dye (Molecular Probes) in phosphate buffer solution (PBS) (Singh et al., 2001). The IC50 values were calculated using linear interpolation from parasiteextract interaction schizont growth inhibition curves (Log of concentration versus percent inhibition) (Mustofa et al., 2007).

\section{In vivo antiplasmodial screening}

Fidock et al. (2004) four-day curative test was employed in this study. Thin and thick tail tip blood smears of mice were pre-screened for rodent parasites using microscopy.

Eighteen Swiss albino mice in the range 15-19 g were selected and shared into five groups of three mice each. Groups I, II and III served as the test groups while groups IV and V were positive and negative control groups and were treated with chloroquine and untreated respectively. Plasmodium berghei (approximately 1 x $10^{7}$ infected red cells) was inoculated via intraperitoneal route into all the mice. The infection was proven in animals at 72 hours post parasite inoculation. After the establishment of infection, mice in groups I - III were orally treated with the crude extract at 100, 200 and $400 \mathrm{mg} / \mathrm{kg}$ bw once daily for 4 days while group IV was treated with5 $\mathrm{mg} / \mathrm{kg}$ bw of Chloroquine phosphate to serve as the positive control group and group $\mathrm{V}$ was given normal saline at $0.9 \mathrm{w} / \mathrm{v}$ to serve as negative control.

Blood smears (both thin and thick) from the tail blood were prepared for each animal on a single slide on days 4, 7, 14, 28 and 42. Methanol was used to fix the thin films, and all of them were stained for 30 minutes with a 3 percent Giemsa stain with a $\mathrm{pH}$ of 7.0. Microscopic examination of the blood films were done using oil immersion (100X) objectives according to WHO (2010). Parasite densities were determined with the thick films while the stages and parasite species were identified using the thin films. Parasite density per microliter of blood 
(parasitemia) was estimated from the thick film, taking the number of leucocytes per microliter of blood as 8,000 and expressed as follows

Parasite density $/ \mu 1=\frac{\text { parasite count } \times \text { 8,000 }}{\text { No of } \text { WBC counted }} \quad$ (WHO, Page | 4156 2010).

\section{Bioassay guided fractionation of crude extract}

The crude Z. zanthoxyloides extract was subjected to column chromatography using silica gel and eluted with solvents of rising polarity (n-hexane, chloroform, ethylacetate and methanol). This afforded /resulted/gave numerous fractions that were grouped according to of their TLC profile. The combined fractions were then dried under a fume-hood. The antiplasmodial effects of the fractions were evaluated as described earlier.

\section{Results}

\section{Percentage Yield}

The extract yield was $2.5 \%$.

In vitro Antiplasmodial Activity of Crude $Z$. zanthoxyloides Extract
The in vitro antiplasmodial activity of crude $Z$. zanthoxyloides extract was higher compared to the standard drugs used while its resistant index was comparable to that of artesunate.

\section{In vivo Antiplasmodial Activity of Crude Z. zanthoxyloides Extract}

A dose dependent effect was observed in the in vivo antiplasmodial activity of crude $Z$. zanthoxyloides extract. Only the positive control group survived beyond day 28. Only the survival time of the positive control was beyond 28 days.

\section{In vitro Antiplasmodial Activity of Fractions $Z$. zanthoxyloides Extract}

The antiplasmodial activities K2, K4 and K6 were higher/better compared to other fractions.

Table 1: In vitro Antiplasmodial Activity of Crude Z. zanthoxyloides Extract against NF54 and K1

\begin{tabular}{|l|l|l|l|}
\hline Extracts/standards & IC $50(\mathrm{ng} / \mathrm{ml}) \mathrm{CQS}(\mathrm{NF} 54)$ & $\mathrm{IC} 50(\mathrm{ng} / \mathrm{ml}) \mathrm{CQR}(\mathrm{K} 1)$ & $\begin{array}{l}\text { Resistance Index }(\mathrm{RI}) \\
\mathrm{IC}_{50} \mathrm{~K} 1 / \mathrm{IC}_{50} \mathrm{NF}\end{array}$ \\
\hline Z. zanthoxyloides & $1076.4 \pm 56.4^{\mathrm{a}}$ & $1315.1 \pm 121.6^{\mathrm{a}}$ & 1.222 \\
\hline CQ $(\mathrm{nM})$ & $10.94 / 3478.92$ & $310.68 / 98796.24$ & 28.39 \\
\hline ART $(\mathrm{nM})$ & $9.24 / 3215.52$ & $10.94 / 3650.52$ & 1.184 \\
\hline
\end{tabular}

Key: $\mathrm{CQ}=$ chloroquine, $\mathrm{ART}=$ artesunate, $\mathrm{CQS}=$ chloroquine sensitive strain and $\mathrm{CQR}=$ chloroquine resistant strain 


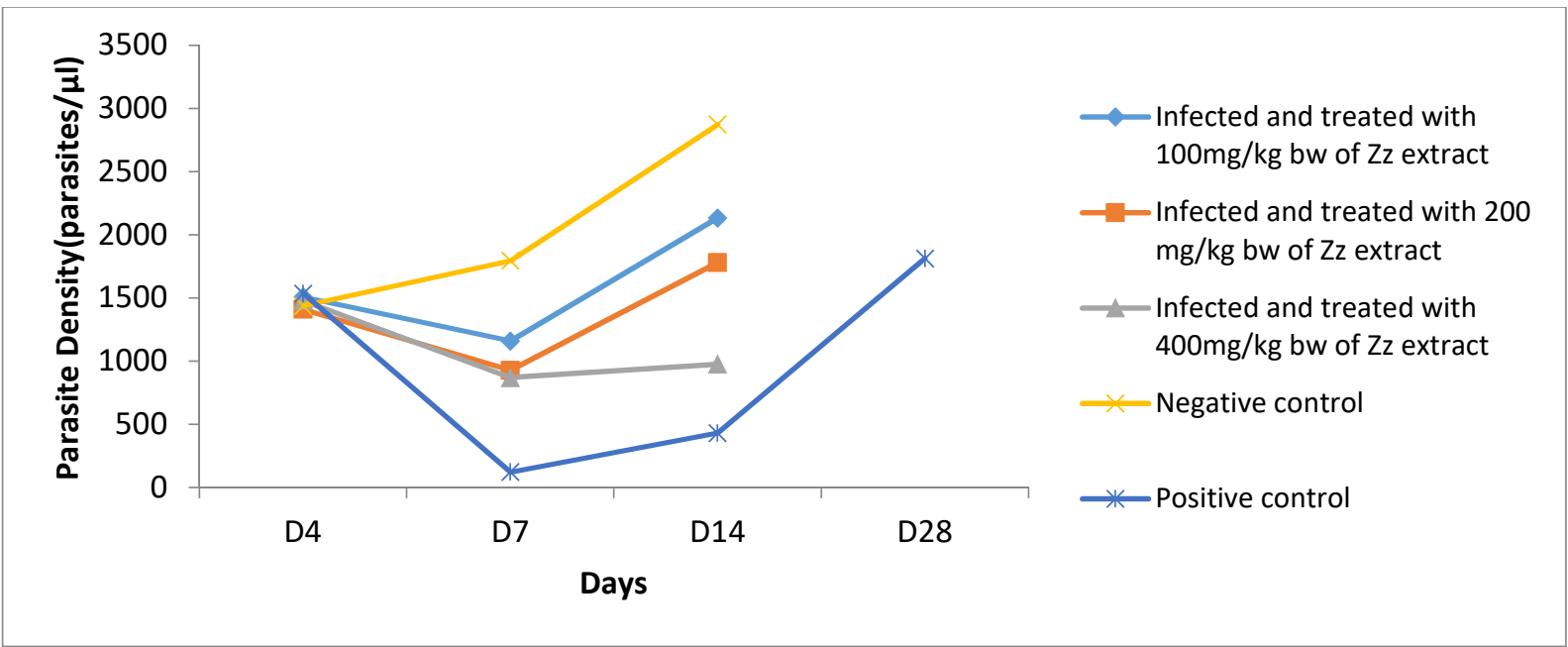

Figure 1: In vivo antiplasmodial activity of $P$. berghei infected mice treated with ethanolic stem bark extract of Zanthoxylum zanthoxyloides.

Table 2: In vitro Antiplasmodial Activity of $Z$. zanthoxyloides fractions against NF54

\begin{tabular}{ll}
\hline Fractions/Standards & $\mathrm{IC}_{50}(\mathrm{ng} / \mathrm{ml}) \mathrm{CQS}(\mathrm{NF} 54)$ \\
$\mathrm{K} 1$ & $>10$ \\
$\mathrm{~K} 2$ & 6.67 \\
$\mathrm{~K} 2$ & 8.53 \\
$\mathrm{~K} 4$ & 6.89 \\
$\mathrm{~K} 5$ & 8.07 \\
$\mathrm{~K} 6$ & 6.48 \\
$\mathrm{~K} 7$ & $>10$ \\
$\mathrm{~K} 8$ & $>10$ \\
CQ(nM) & $10.94 / 3478.92$ \\
ART(nM) & $9.24 / 3215.52$ \\
\hline
\end{tabular}

NB: K1 - K8 are the fractions, while CQ is the chloroquine phosphate and ART is the artesunate

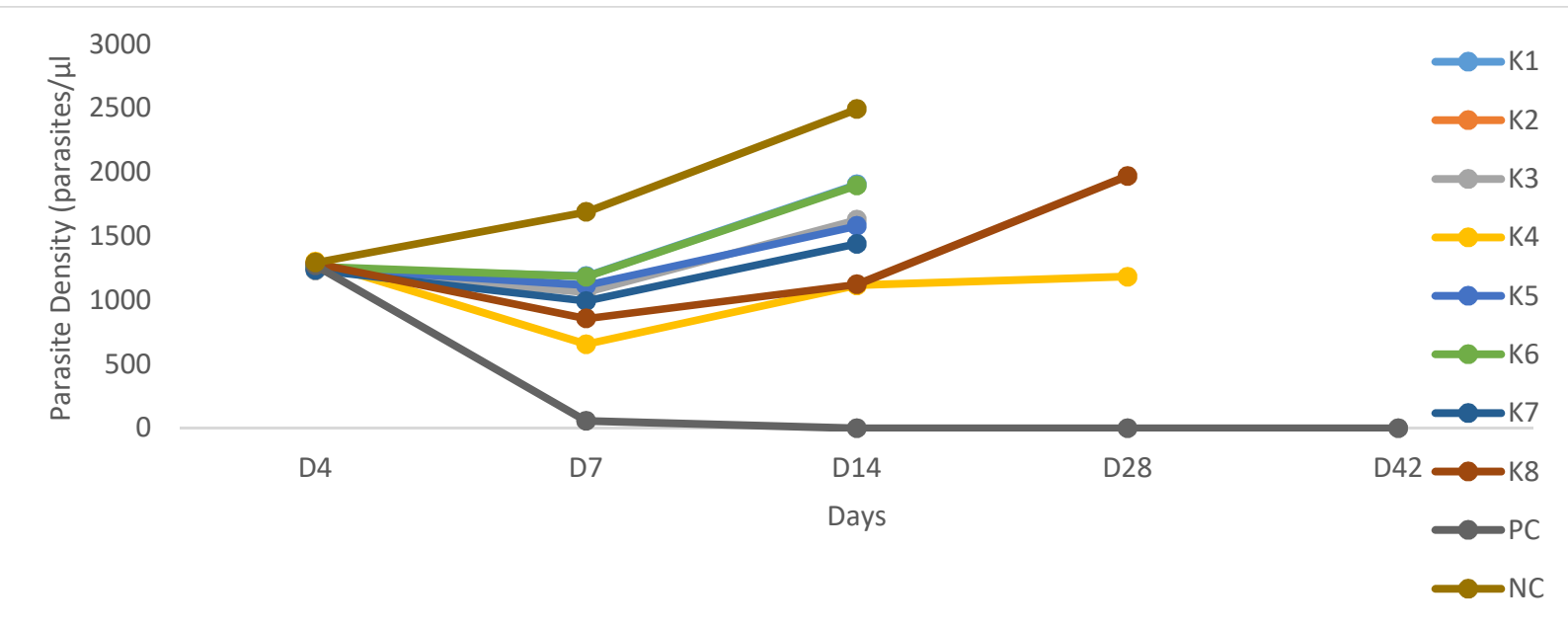

Figure 2: In vivo antiplasmodial activity of $P$. berghei infected mice treated with column fractions of Zanthoxylum zanthoxyloides stem bark extract.

NB: K1 - K8 are groups treated the fractions, while PC is the standard control (chloroquine phosphate) and $\mathrm{NC}$ is the negative control (Normal saline treated). 


\section{Discussion}

Generally, the benchmarks for measuring antiplasmodial effect against $P$. falciparum according to World Health Organization are: Page | 4158 pronounced activity for $\mathrm{IC}_{50}<5 \mu \mathrm{g} / \mathrm{ml}$, good activity for $5 \mathrm{IC}_{50}<10 \mu \mathrm{g} / \mathrm{ml}$, moderate activity for $10<\mathrm{IC}_{50}<20$, low activity for $20<\mathrm{IC}_{50}<40$ $\mu \mathrm{g} / \mathrm{ml}$ and inactive for $\mathrm{IC}_{50}<40 \mu \mathrm{g} / \mathrm{ml}$ (Nyongbela et al., 2016). As a result, antiplasmodial activity was found pronounced in $Z$. zanthoxyloides fractions. This is because, based on the results of the in vitro antiplasmodial test, $Z$. zanthoxyloides extract could be a viable alternative to artesunate as an antiplasmodial drug due to similarity in resistance index. Resistance Index (DRI) is a measure of drug effectiveness in relation to drug resistance, which is caused by misuse and overuse of medications. A corner- stones in the fight against drug resistance is the restrictive use of medications (Vandenbroucke-Grauls et al., 2019). It has been previously documented that the lower the resistance index the better the antiplasmodial agent against resistant strain of the parasite (Joseph et al., 2017). The in vitro antiplasmodial assay had also shown this extract to be a superior antiplasmodial agent compared to chloroquine. Presently, Z. zanthoxyloides extract could provide substitute antiplasmodial agent in Africa, where $P$. falciparum resistance is prevalent/predominant and in Asia where multidrug resistance $\mathrm{K} 1$ strain emanate (Saifi et al., 2013). The extraordinary in vitro action could be ascribed to the fact that only the non-protein-bound fraction of a medication is pharmacologically active in vivo, which makes the serum effect to be considered amid treatment administration (Li et al., 2017). The outcomes of in vitro assay constantly require to be guaranteed in in vivo settings, since living systems are more complex and dynamic in nature/framework.

The in vivo antiplasmodial effect was in a concentration dependent manner. As the dose of extract increases the parasite density decreases. The antiplasmodial property of this extract could be linked to its ability either inhibit plasmodium parasite growth or destruction of parasite infected erythrocytes (Tajuddeen and Van Heerden, 2019). The distinction recorded/perceived in antiplasmodial action during the in vivo test may well be accredited to the rise in the concentration of antiplasmodial agent in the extract as the dosage increases (Nyandwaro et al., 2020).

The in vitro antiplasmodial testing of the fractions resulted in diminished antiplasmodial property of the crude extract compared to the fractions. The bioactive component responsible for the effect could have been chemically altered during the fractionation process, which could explain the observed decrease in antiplasmodial activity. Another reason could be more than one active principle in the crude extract working synergistically to elicit the antiplasmodial activity separation of which had resulted in a diminished antiplasmodial activity. Lopes et al. (2013) reported a related observation with crude extract having higher activity compared to the fractions. Moreover, halogen containing solvents are identified to affect/modify alkaloids basically and consequently may adjust/alter their action. Chloroform utilized amid the course of fractionation may be accountable for the recorded changes. Elution with chloroform on silica gel columns containing quaternary alkaloids such as berberine and palmatine are known to create adduct chloroform compounds (Maltese et al., 2009), which could be accountable for a decline or complete lost in activity of compound. In this research there was a decrease in activity of the fractions compared to the crude extract.

Furthermore, previous studies have shown $Z$. zanthoxyloides extract contain berberine and benzophenanthridine, chelerythrine (Orafidiya et al., 2010, Adesina, 2005). These two substances are potent antiplasmodial agents (Bekono et al., 2020). Berberine's antimalarial activity has been studied in vitro against the mefloquine-resistant D-6 clone of Plasmodium falciparum, as well as 
sulfadoxine, pyrimethamine, chloroquine and quinine-resistant W-2 clone (Chandel et al., 2015). Similarly, Z. zanthoxyloides has produced nitidine, an antimalarial chemical (Patel et al., 2010). Instead of directly affecting the

Page | 4159 biocrystallization process in the vacuole, nitidine is thought to disrupt the interaction between glutathione (a biological antioxidant) and haem in the parasite's cytoplasm (Bouquet et al., 2012). As a result, the parasite suffers from heme poisoning.

Other species from Zanthoxylum family also contain antiplasmodial agent nitidine (Muganga et al., 2014). In addition, Perala and Ciddi, (2018) reported the occurrence of chelerythrine in the extract of Zanthoxylum rhetsa. This plant belongs to the same family with $Z$. zanthoxyloides. Additionally, antimalarial viability has pharmacologically been proven/demonstrated (Gansane et al., 2010). Kassim et al., (2005) illustrated the root extract of $Z$. zanthoxyloides possess in vitro anti-malarial property against 3D7 strain of $P$. falciparum and have attributed its activity to benzophenanthridine alkaloid, fagaronine. However, in this study the antiplasmodial efficacy of the stem bark extract was tested in vitro and in vivo, and also against $\mathrm{K} 1$ of $P$. falciparum. $\mathrm{K} 1$ is a multidrug resistant of $P$. falciparum parasite (Pan et al., 2018). The K1 strain used in this study is known to be resistant to Chloroquine and sulfadoxine (antimalaraial drugs). Z. zanthoxyloides could provide a good candidate against resistant strains of $P$. falciparum.

Because the extract exhibited a decrease in $\mathrm{IC}_{50}$ of the K1 compared to the NF54 strain of $P$. falciparum, it will be useful lead for the creation of novel medicine, especially in Africa where chloroquine and sulfadoxine resistance has been widely reported/documented. While $Z$. zanthoxyloides extract exhibited an index that was comparable to Artsunate, it was significantly below the resistant index for chloroquine (standard antimalarial drug). The lower the resistance index in contrast to chloroquine, the better the antiplasmodial agent, it has been claimed (Joseph et al., 2017).

\section{Conclusion}

Finally, this research has established that ethanolic extracts of $Z$. zanthoxyloides stem bark exhibit exceptional antiplasmodial efficacy against both chloroquine susceptible and drug resistant $P$. falciparum, supporting it ethnomedicinal use in malaria treatment. Antiplasmodial activity of $Z$. zanthoxyloides against the multidrug-resistant $\mathrm{K} 1$ strain of Plasmodium falciparum seems promising. $Z$. zanthoxyloides extract has promising antiplasmodial activity and could be used to create/generate therapeutic leads against the multidrug-resistant $\mathrm{K} 1$ strain of $P$. falciparum, in addition to providing an alternative to allopathic antiplasmodial medicines

\section{Competing Interest}

The authors declare no competing interests

\section{References}

Addisu, A., Tegegne, Y., Mihiret, Y., Seteggn, A. and Zeleke, A. J. (2020). A seven year trend of malaria at primary health facilities in Northwest Ethiopia. Journal of Parasitology Research, 2020(4204987), 5.

Adekunle, A., Kamdem, J. and Rocha, J. (2012). Antioxidant activity and HPLC analysis of Zanthoxylum zanthoxyloides. Report Opinion, 4(3), 6-13.

Adesina, D. A., Adefolalalu, S. F., Jigam, A. A. and Lawal, B. (2020). Antiplasmodial effect and subacute toxicity of alkaloids, flavonoids and phenolic extracts of Sida acuta leaf on Plasmodium berghei-infected animals. Journal of Taibah University for Science, 14(1), 943-953. 
Adesina, S. K. (2005). The Nigeria Zanthoxylum; The chemical and biological values. Africa Journal Traditional, Complementary and Alternative Medicines, 2(3), 282-301.

Page | 4160 Aloke, C., Nwachukwu, N., Ugwuja, E. I., Idenyi, J. N., Nwachi, E. U., Obasi, I. O. and Oga, O. (2012). Effects of Zanthoxylum zanthoxyloides leaves on blood glucose, lipid profile and some liver enzymes in alloxan induces diabetic rats. International Journal of Science and Nature, 3(3), 497-501.

Barnabas, B. B., Mann, A., Ogunrinola, T. S., and Anyanwu, P. E. (2011). Short Communication Screening for anthelminthic activities from extracts of Zanthoxylum zanthoxyloides, Neocarya Macrophylla and Celosia Laxa against Ascaris Infection in Rabbits. International Journal of Applied Research Nature, Products, 3, 1-4.

Bekono, B. D., Ntie-Kang, F., Onguéné, P. A., Lifongo, L. L., Sippl, W., Fester, K., Luc, C. O. and Owono1, L.O. (2020). The potential of anti-malarial compounds derived from African medicinal plants: a review of pharmacological evaluations from 2013 to 2019. Malaria Journal, 19, 183.

Bouquet, J., Rivaud, M., Chevalley, S., Eric, F., Deharo, E., Jullian, V. and Valentin. A. (2012). Biological activities of nitidine, a potential anti- malarial lead compound. Malaria Journal, 11, 67.

Chaaiba, F., Queiroz, E. F., Ndjoko, K., Diallo, D., and Hostettmann, K. (2003). Antifungal and antioxidant compounds from the root bark of Fagara zanthoxyloides. Planta Medica, (69), 316-320.

Chandel, S., Bagai, U., Semwal, R. B. and Semwal, D. P. (2015). Antiplasmodial activity of aqueous extract of Berberis aristata roots against Plasmodium bergheiinfected BALB/c mice. Pharmaceutical Biology, 53(12), 1735-1740.

Denloye, A., Makanjuola, W., Ajelara, O., Akinlaye, O., Olowu, R. and Lawal, O. (2010). Toxicity of powder and extracts of Zanthoxylum zanthoxyloides Lam (Rutaceae) root bark from Nigeria to three storage beetles. Julius-Kühn-Archiv p 833.

Diatta, W., Sy, G. Y., Manga, C. I., Diatta, K., Fall, A. and Bassene, E. (2014). Recherche des activités anti-inflammatoireet analgésique des extraits de feuilles de Zanthoxylum zanthoxyloides (Lam) zepernick et timler (Rutaceae). International Journal of Biological and Chemical Sciences, (8), 128-133.

Fidock, D. A., Rosenthal, P. J., Croff, S. L., Brun, R. and Nwaka, S. (2004). Antimalarial drug discovery: efficacy models for compound screening. Nature Review, 3, 509-520.

Fogang H.P., Azefack, T., Hilaire, W., Luana, Q., Massimo, B., Luca, V., Dezemona, P., Giulio, L., Filippo, M., Fabrizio, P., Sauro, V. and Luciano, B. (2012). Characterization and biological activity of essential oils from fruits of Zanthoxylum xanthoxyloides Lam. and Z. Leprieurii Guill. Perr., two culinary plants from Cameroon. Flavour and Fragrance Journal, 27(2), 171-179.

Forkuo, A. D., Mensah, K. B., Ameyaw, E.O., Antwi, A.O., Kusi-Boadum, N. K., and Ansah, C. (2020). Antiplasmodial activity and safety evaluation of methanolic leaf extract of Murraya exotic (L). Journal of Parasitology Research, 2020(1308541), 8.

Gansane, A., Sanon, S., Ouattara, P. L., Hutter, S., Ollivier, E., Azas, N., Traore, A., Traore, A. S., Guissou, Nebie, I. and Sirima, B. S. (2010). Antiplasmodial activity and 
cytotoxicity of semi purified fraction from Zanthoxylum zanthoxyloides Lam bark of Trunk. International Journal of Pharmacology, 6(6), 921-925.

Page | 4161 Grigg, M. J and Snounou, G (2017). Plasmodium simium: A Brazilian focus of anthropozoonotic vivax malaria? The Lancet Global Health, 5:e961-e962.

Guendehou, F., Djossa, B. A., Kenou, C. and Assogbada, C. A. E. (2018). Review of studies on Zanthoxylum zanthoxyloids (Lam): availability and ethnomedicinal, phytochemical pharmacological uses. Scholars Journal of Research in Agriculture and Biology, 3(3), 244-254.

Imaga, N. O. A., Shaire, E. A., Ogbeide, S. and Samuel, A. K. (2011) "In vitro biochemical investigations of the effects of Carica papaya and Fagara zanthoxyloides on antioxidant status and sickle erythrocytes." African Journal of Biochemistry Research, 5(8), 226-236.

Joseph, A. A., Odimayo, M. S., Olokoba, L. B., Olokoba, A. B. and Popoola, G. O. (2017). Multiple antibiotic resistance index of Escherichia coli isolates in a tertiary hospital in South-West Nigeria. Medical Journal of Zambia, 44(4), 225-232.

Kassim, O. O., Copeland, R. L., Kenguele, H. M., Nekhai, S., Ako-Nai, K. A., and Kanaan, Y. M. (2015). Antiproliferative activities of Fagara xanthoxyloides and Pseudocedrela kotschyi against prostate cancer cell lines. Anticancer Research, (35),1453-1458.

Kassim, O.O., Loyevsky, M., Elliott, B., Geall, A., Amonoo, H. and Gordeuk, V. R. (2005). Effects of root extracts of Fagara zanthoxyloides on the in vitro growth and stage distribution of Plasmodium falciparum. Antimicrobial Agents and Chemotherapy, 49(1), 64-268.
Larsen, B. H. V., Soelberg, J. and Jager, A. K. (2015). COX-1 inhibitory effect of medicinal plants of Ghana. South African Journal of Botany, (99), 129-131.

Li, J., Xie, S., Ahmed, S., Wang, F., Gu, Y., Zhang, C., Chai, X., Wu, Y., Cai, J. and Cheng, G. (2017). Antimicrobial activity and resistance: influencing factors. Frontiers in Pharmacology, 8, 364.

Lopes, A. P., Bagatela, B. S., Rosa, P. C. P., Nanayakkara, D. N. P., Carvalho, J. T., Maistro, E. L., Bastos, J. K. and Pera, F. F. (2013). Antioxidant and cytotoxic effects of crude extract of $Z$. zanthoxyloides, fractions and 4-nerolidylcathecol from aerial parts of Pothomorphe umbellate L. (Piperaceae). Biomedical Research International, 2013, 206581.

Maltese, F., van der Kooy, F. and Verpoorte, R. (2009). Solvent Derived Artifacts in Natural Products Chemistry. Natural Product Communications, 4 (3), 447-454.

Maximin, K. A., Loset, J. R., Loset, K. N., Diallo, D., Mauel, J. and Hostettmann, K. (2007). Antileishmanial activities associated with plants used in the Malian traditional medicine. Journal of Ethnopharmacology 110, 99-104.

Muganga, R., Angenot, L., Tits, M. and Frédérich, M. (2014). In vitro and in vivo antiplasmodial activity of three Rwandan medicinal plants and identification of their active compounds. Planta Medica, 80, 482-489.

Mustofa, J., Sholikhah, E. N. and Wahyuono, S. (2007). In vitro and in vivo antiplasmodial activity and cytotoxicity of extracts of Phyllanthus niruri L. herbs traditionally used to treat malaria in Indonesia. Southeast Asian Journal of Tropical Medicine and Public Health, 38(4), 609-615. 
Nurain, I. O., Bewaji, C. O., Johnson, J. S. and Davenport, R. D (2017). Potentials of three ethnomedicinal plants as antisickling agents. Molecular Pharmaceutics, 14, 172182.

Nyandwaro, K., Oyweri, J., Kimani, F. and Mbugua, A. (2020). Evaluating antiplasmodial and antimalarial activities of soybean (Glycine max) seed extracts on $P$. falciparum parasite cultures and $P$. berghei infected mice. Journal of Pathogens, 2020(7605730), 8 .

Nyongbela, R. D., Makolo, F. L., Hoye, T. R. and Efange, S. M. N. (2016). Isolation and characterization of sclerinone $\mathrm{C}$ from Scleria striatinux. Natural Product Communications, 11, 5-6.

Orafidiya, L.O., Akinkunmi, E. O., Oginni, F. A. and Oluwamakin, A. (2010). Effectiveness of extracts of the root of Zanthoxylum zanthoxyloides (Linn.) waterman (rutaceae) formulated as toothpaste. Nigeria Journal of Natural Product and Medicine, 14, 2126.

Pan, W., Xu, X., Shi, N., Tsany, S.W. and Zhang, H. (2018). Antimalarial activity of plant metabolites. International Journal of Molecular Sciences, 19(1382), 1-40.

Patel, B., Das, S., Prakash, R. and Yasir, M. (2010). Natural bioactive compound with anticancer potential. International Journal of Advances in Pharmaceutical Sciences $1(1), 32-41$.

Pauline, N., Cabral, B. P., Anatole, P. C., Jocelyne, A. V., Bruno, M. and Jeanne, N. Y. (2013). The in vitro antisickling and antioxidant effects of aqueous extracts Zanthoxyllum heitzii on sickle cell disorder. BioMedical Central Complementary and Alternative Medicine.13, 162.
Perala, K. and Ciddi, V. (2018). Simultaneous quantitative determination of nitidine, Chelerythrine and sanguinarine using HPTLC from Callus extract of Zanthoxylum rhetsa. American Journal of Analytical Chemistry, 9, 386-396.

Queiroz, E. F., Hay, A., Diemen, D., Chaaib, F., Diallo, D. and Hostettman, K. (2006). New and bioactive aromatic compounds from Zanthoxylum zanthoxyloides. Planta Medica, 72: e213-e216.

Saifi, M. A., Beg, T., Harrath, A., Altayalan, F. S. H. and Al Quraishy, S (2013). Antimalarial drugs: Mode of action and status of resistance. African Journal of Pharmacy and Pharmacology, 7(5), 148-156.

Singh, A. and Rosenthal, P. J. (2001). Comparison of efficacies of cysteine protease inhibitors against five strains of Plasmodium falciparum. Antimicrobial Agents and Chemotherapy, 45, 949-951.

Tajuddeen, N. and Van Heerden, F. R. (2019). Antiplasmodial natural products: an update. Malaria Journal, 18, 404.

Talapko, J., Skrlec, I., Alabic, T., Jukic, M. and Vcev, A. (2019). Malaria: The past and the present. Microorganisms, 7, 179.

Udo, I. (2011). Potentials of Zanthoxylum zanthoxyloides (Lam) for the control of stored product insect pest. Journal of Stored Products and Postharvest Research, 2, 4044.

Vandenbroucke-Grauls C. M. J. E., Kahlmeter, G., Kluytmans, J., Kluytmansvan den Bergh, M., Monnet, D. L., Simonsen, G. S., Skov, R. L., Sonksen, U. W. and Voss, A. (2019). The proposed drug resistance index (DRI) is not a good measure of antibiotic effectiveness in 
relation to drug resistance. BMJ Global Health, 2019;4:e01838.

World Health Organisation (2010). Basic malaria microscopy, part I: Learner's guide, $2^{\text {nd }}$ Page | 4163 edition, WHO graphics, Switzerland, pp75.

World Health Organisation (2021). The "World malaria report 2019" at a glance.

Wouatsa, V. A., Misra, L., Kumar, S., Prakash, O., Khan, F., Francois, T. and Kumar, R.V. (2013). Aromatase and glycosyl transferase inhibiting acridone alkaloids from fruits of Cameroonian Zanthoxylum species. Chemistry Central Journal, 7(1), 125.
Ynalvez, R. A., Cardenas, C., Addo, J. K., Adukpo, G. E., Dadson, B. A. and Mensah, A. A. (2012). Evaluation of antimicrobial activity of $Z$. zanthoxyloides root bark extracts. Research Journal of Medicinal Plant, 6(2), 149-159.

Zhou, G., Guo, S., Luo, Y., Ye, L., Song, G., Guo, L., Chen, Y., Han, L. and Yang, J. (2014). NDM-1producing strains, family Enterobacteriaceae in hospital, Beijing, China. Emerging Infectious Diseases, 20, 340-342. 